\title{
Remembering Emeritus Professor Arnold L. Demain (April 26, 1927-April 3, 2020)
}

\author{
Satoshi Ōmura ${ }^{1}$
}

Published online: 28 May 2020

(c) The Author(s), under exclusive licence to the Japan Antibiotics Research Association 2020

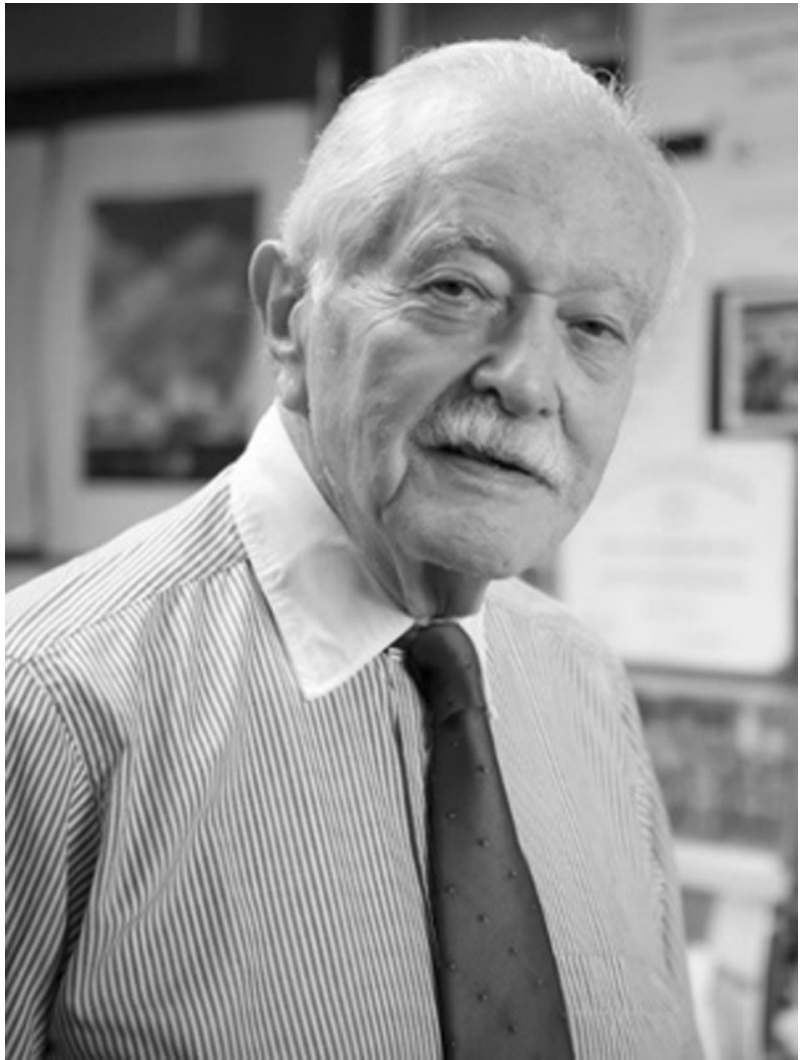

Professor Arnold Lester Demain, Arny, passed away on Friday, April 3, 2020 at the age of 92 from complications due to COVID-19.

Arny became a Member of the Editorial Board of The Journal of Antibiotics (JA) on its internationalization in 1968, and an Emeritus Member of the Board in 1998. JA published in 2010 a special dedication issue to Arny to

Satoshi Ōmura

omuras@insti.kitasato-u.ac.jp

Editor-in-Chief Emeritus The Journal of Antibiotics, Tokyo, Japan thank his outstanding and exemplary service to the journal for such a long time. On behalf of the Editorial Board and as the Editor-in-Chief Emeritus of JA, I would respectfully offer heartfelt condolences on the death of Arny.

Before joining to Massachusetts Institute of Technology (MIT) in 1969, Arny worked at Merck Sharp \& Dohme Research Laboratories (MSDRL) as the Head of Department of Fermentation Microbiology, under the direction of Dr. Max Tishler, to boost production yields of vitamin B12. I worked between 1971 and 1973 at Wesleyan University as a visiting professor under the direction of Professor Max Tishler right after his moving from MSDRL in 1970. In this respect, Arny and I shared the same mentor although the time and the place different.

At MIT, Arny investigated production of microbial products either primary or secondary metabolites including antibiotics how they are biosynthesized.

Among 570 publications of Arny, over than 20 original articles were published in JA on the subject of $\beta$-lactam antibiotics (penicillins and cephalosporins), rapamycin, platensimycin, and other bioactive microbial products; the first article on streptomutin in 1975 under the authorship with a Japanese postdoctoral fellow at MIT, and the last one on platensimycin in 2017 with 20 graduate and undergraduate students of the Research Institute for Scientists Emeriti program, Charles A. Dana Research Institute, Drew University.

The subscribers of JA have received benefits from Arny's profound knowledge of microbial products via review articles contributed on some occasions such as: "Cell-free systems and the fungal biosynthesis of beta-lactams" in the dedication issue to the Late Sir Edward Abraham in 2000, "Microbial drug discovery: 80 years of progress" on the 60 years anniversary of the journal in 2009, "Production of valuable compounds by molds and yeasts" in the dedication issue to Prof Julian E. Davies in 2017, "The antibiotic resistance crisis, with a focus on the United States" in the dedication issue to Prof Satoshi Ōmura in 2017, and "Our microbes not only produce antibiotics, 
they also overproduce amino acids" in the dedication issue to the Late Prof Hamao Umezawa in 2018 on the occasion of the 60th anniversary of global kanamycin marketing.

Arny also contributed greatly to the publisher of JA, Japan Antibiotics Research Association (JARA), to giving a plenary lecture in 1979 at the 30th anniversary of the journal under the title of "Aminoglycosides, genes and regulation", and to editing the proceedings on an international symposium on "Trends in Antibiotic Research" in 1982 along with a plenary lecture under the title of "Microbiological synthesis of $\beta$-lactam antibiotics".

Beside JA, Arny made significant contributions to microbiological and biotechnological societies. Giving lectures under the titles of "Genetics and process improvement in Streptomyces" at the 4th International Fermentation Symposium on Fermentation Technology Today, held in 1972 in Osaka, organized by the Society of Fermentation Technology, those of "Enzymatic synthesis of useful products" and "Regulation of secondary metabolism by primary metabolites" at the 1st Intersectional Congress of the International Association of Microbial Societies (IAMS), held in Tokyo in 1974, organized by Science Council of Japan, that of "Regulation of $\beta$-lactam antibiotic production" at the 4th International Symposium on Genetics of Industrial Microorganisms (GIM), held in Kyoto in 1982, that of "The in vivo longevity of antibiotic synthetases" in a book "Horizons of Biochemical Engineering" published in 1987 by the Society of Fermentation Technology Japan, and that of "Actinomycetes: What have you done for us lately?" as the Closing Plenary Lecture of the 7th International Symposium on the Biology of Actinomycetes, held in Tokyo in 1988, organized by the Society for Actinomycetes, Japan (SAJ).

In 1985, Honorary Membership of the Kitasato Institute was conferred to Arny when I directed the institute, and the Microbial Chemistry Medal of the Kitasato Institute and Kitasato University was conferred to him in 1988.
In 1991, Arny presented me the Charles Thom Award of the Society for Industrial Microbiology, U.S.A., as the President of the society.

In 1995, Honorary Membership of the SAJ was conferred to him, following Dr. H. Boyd Woodruff who was an honorary member of the Kitasato Institute.

Arny was conferred the Medal of the Order of the Rising Sun, Imperial Decoration Award, in 1999, for his great contribution on microbial biotechnology through his mentorship of many Japanese scientists for a long time.

The 1st Symposium on Industrial Microbiology \& Biotechnology, which was subtitled "A Celebration of Arny's Army \& Friends (AA\&F)", was held in 1995 in Cambridge, MA, USA, followed by the 2nd in 1997 in Nara, Japan, the 3rd in 1999 in Gent, Belgium, the 4th in 2001 in Merida, Mexico, and 5th in 2003 in Shanghai, China. Then the year of 2007 was the special year for AA\&F to celebrate Arny's age of 80 as follows. The 6th AA\&F symposium came back to MIT, Cambridge in August and subsequently the two special symposia were held in November in Osaka and Tokyo by AA\&F and SAJ, respectively.

In 2011 in Sapporo, at the Congress of International Union of Microbiological Societies (IUMS), Arny gave a lecture at the memorial symposium dedicated to the Late Dr. Shukuo Kinoshita with whom he kept great camaraderie for half a century. At the same occasion, an Editorial Board meeting of JA was held under the participation of Arny.

Arny was a great scientist, mentor, colleague, and friend in the research on antibiotics and other bioactive microbial products. His contributions to the scientific community were so enormous and he will be missed by all.

With edits from Drs. Kunimoto Hotta and Morimasa Yagisawa.

Satoshi Ōmura, Ph.D.

Editor-in-Chief Emeritus

The Journal of Antibiotics 